\title{
Contrasting Genesis of Lateritic Bauxite on Granodioritic and Andesitic Rocks of Mempawah Area, West Kalimantan
}

\author{
Deni Mildan $^{1 *}$, Andri S. Subandrio ${ }^{1}$, Prayatna Bangun ${ }^{2}$, Dedi Sunjaya ${ }^{2}$ \\ ${ }^{1}$ Geological Engineering, Institut Teknologi Bandung, \\ Ganesa St., No.10 Kota Bandung, Jawa Barat 40132, Indonesia \\ ${ }^{2}$ PT ANTAM Tbk., Jakarta Selatan \\ Aneka Tambang Building Tower A, Letjen. T.B. Simatupang St., No. 1, Jakarta 12530, Indonesia \\ *E-mail: deni.mildan@gmail.comailto
}

Article received: 8 July 2021, revised: 16 August 2021, accepted: 29 August 2021

DOI: $10.51835 /$ iagij.2021.1.2.33

\begin{abstract}
The lateritic bauxite deposits in the Mempawah area, West Kalimantan, were formed by the chemical weathering of Cretaceous granodioritic and andesitic rocks. They occurred locally on the low hills surrounded by swampy areas. Detailed surface geological mapping, test pits, mineralogical and geochemical analyses were performed to determine the characteristics and genesis of bauxite from different parent rocks. From bottom upward, the deposits are composed of fresh parent rocks, clay or pallid zone, bauxite zone with a few sparse ferricrete at the top of the bauxite zone, and soil. Bauxite derived from granodiorite exhibits brownish-red, massive, boulder to gravel-sized concretion in clay matrix and is composed of predominant gibbsite with subordinate kaolinite, quartz, goethite, and a minor amount of magnetite and hematite. In contrast, bauxite derived from andesitic rocks exhibits reddish-brown and is composed of predominant goethite. During the leaching process, $\mathrm{SiO}_{2}$ as a mobile compound decreased significantly in neutral $\mathrm{pH}$, while $\mathrm{Al}_{2} \mathrm{O}_{3}$ and $\mathrm{Fe}_{2} \mathrm{O}_{3}$ precipitated as residual materials to form bauxite concretion. The enrichment anomaly of bauxite derived from andesitic rocks is caused by physio-chemical changes from hydrothermal alteration. Bauxite was formed by indirect bauxitization through the leaching of primary minerals under a tropical-humid climate.
\end{abstract}

Keywords: Bauxite, $\mathrm{Al}_{2} \mathrm{O}_{3}$, gibbsite, leaching, physio-chemical

\section{INTRODUCTION}

Alumina, one of the demanding materials for industry, is used for beverage cans or alloy compounds for aircraft materials [1]. The increasing demand for alumina causes the increasing volume of bauxite production in the last decade. In 2018, global bauxite consumption reached 5.1 million tons, or approximately $30 \%$ higher than that in 2017 which made up 3.9 million tons [2].

Variation of mineralogy and lateritic bauxite characteristics has a strong relationship with the main factor, particularly for the textural and mineralogical composition of their parent rocks, according to Bardossy and Aleva, 1990 within [3]. It suggests that the characteristics have been affected by the genetic occurrence of bauxite laterite. To optimize the mining operation and production, domaining should be performed accurately according to the specific bauxite characteristics.

\section{REGIONAL GEOLOGY}

The study area is located in the Mempawah area, West Kalimantan, which is known as one of the bauxite prospect locations in Indonesia. This area belongs to the bauxite belt of West Kalimantan [4] (Figure 1). 


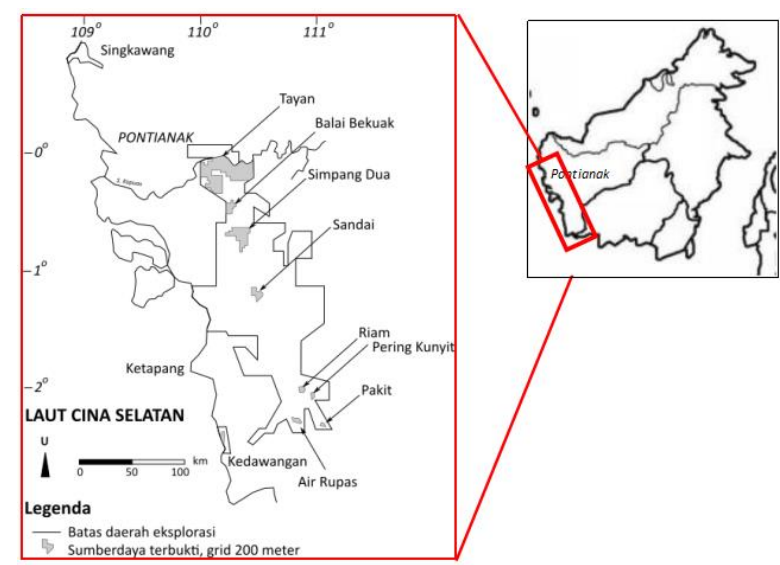

Figure 1. Bauxite lateritic belt in West Kalimantan [4].

According to the geological map of Singkawang sheet, West Kalimantan [5], the research area consists of three formations, i.e., Gunungapi Raya Rock Formation, Mensibau Granodiorite, and the youngest formation of Alluvial and Marsh Deposits. Gunungapi Raya Rock Formation comprises altered andesite, dacite, mixed-basal rocks of andesitic and dacitic pyroclasts which contain abundant chlorite, epidote, thin conglomerate intercalation, sandstone and Early Cretaceous mudrock. These rocks are partly metamorphosed by Cretaceous and Tertiary intrusion, hence altered to pyrite, chalcopyrite, molybdenite, arsenopyrite and sphalerite [6]. Mensibau Granodiorite Formation consists of early to late Cretaceous granodiorite, granite, quartz diorite, diorite, adamellite, and tonalite. Alluvial and marsh deposits comprise recent mud, sand, pebble and plant remnant deposits.

\section{DATA AND METHOD}

The research has been carried out using surface geological mapping and test pits. Samples used in this study include fresh parent rock, bauxite and clay samples. About 16 samples were analyzed using petrography and 12 samples for mineragraphy analyses. Two samples of bauxite were used to identify the mineralogy composition. Meanwhile, 2 samples of fresh rock, 2 clay samples and 28 bauxite samples were analyzed using XRF to observe the enrichment pattern of some major oxide, such as total $\mathrm{SiO}_{2}, \mathrm{Al}_{2} \mathrm{O}_{3}$, and $\mathrm{Fe}_{2} \mathrm{O}_{3}$. Bauxite samples were taken systematically from test pits, particularly 2 meters for each interval from the total thickness of bauxite.

\section{RESULT AND DISCUSSION Field Observation}

Field observation has been conducted for some fresh outcrops and weathered rocks. Field study reveals 3 types of lithology, from older to young rock units consists of andesite, granodiorite and alluvium deposit in Figure 2.

Andesite exhibits greenish-grey, massive structure, holocrystalline, in equigranular, porphyritic-aphanitic texture and composed of plagioclase, hornblende and olivine. Andesite underwent hydrothermal alteration of propylitic, as evidenced by the presence of altered minerals, such as secondary quartz, chlorite, epidote, pyrite, chalcopyrite and sphalerite (Figure 3b).

Granodiorite exhibits light grey, massive, holocrystalline, equigranular and phaneritic texture. Microscopically, granodiorite is composed of plagioclase, quartz, hornblende, biotite and orthoclase with a crystal size of 0.1 to $2 \mathrm{~mm}$ (Figure 3a). Magnetite locally presents as inclusion within biotite, while plagioclase and orthoclase minerals are locally replaced by fine-sized sericite.

Alluvial deposits comprised of loose clayey to pebbly-sized clastic materials, produced by weathering processes of the older rocks. Meteoric water mainly contributes as the weathering agent and sediment transportation. The existence of alluvium deposits is characterized by lowland morphology, surrounded by hill topography. 


\section{IAGI Journal}
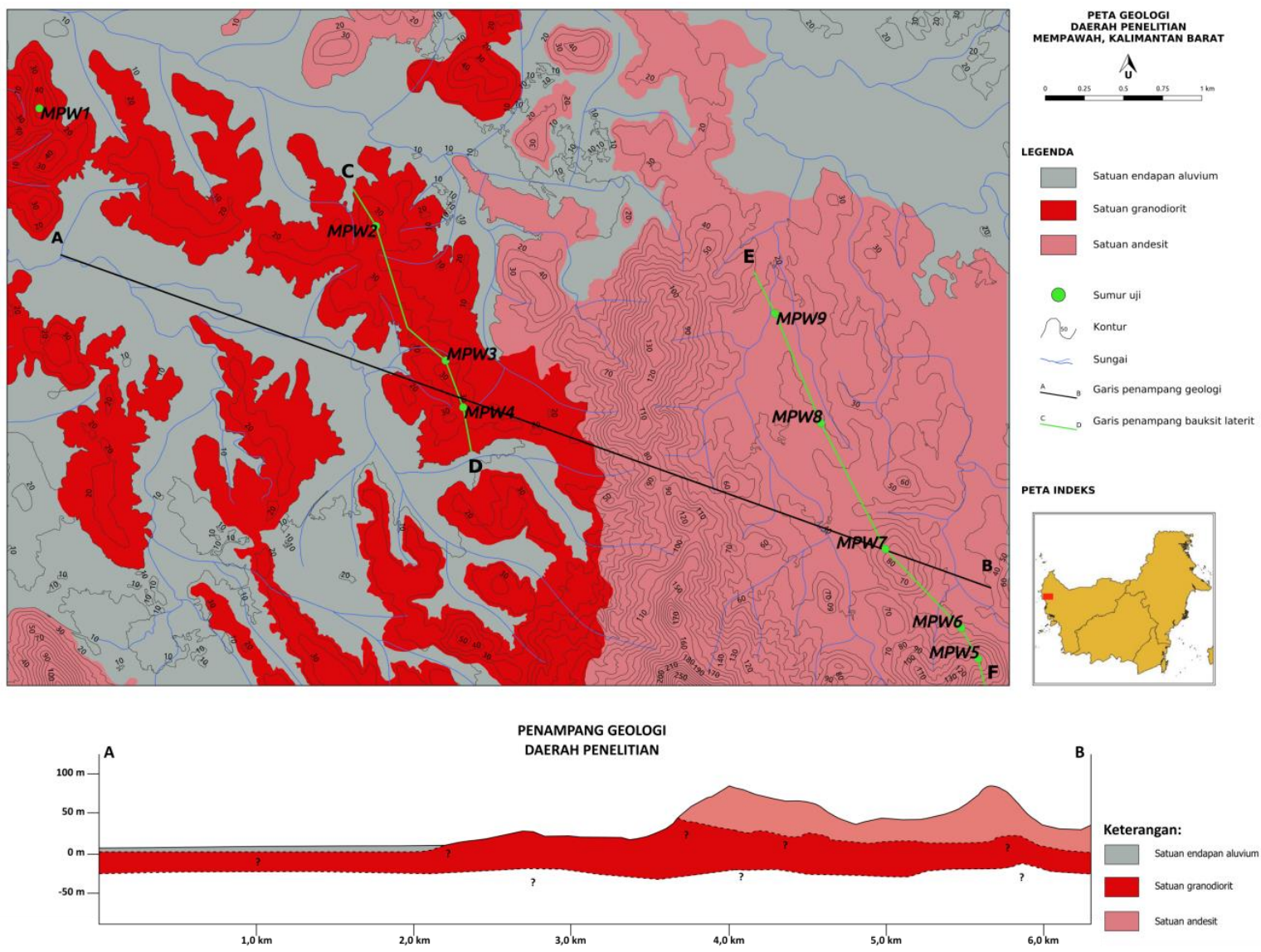

PENAMPANG BAUKSIT LATERIT

DAERAH PENELITIAN

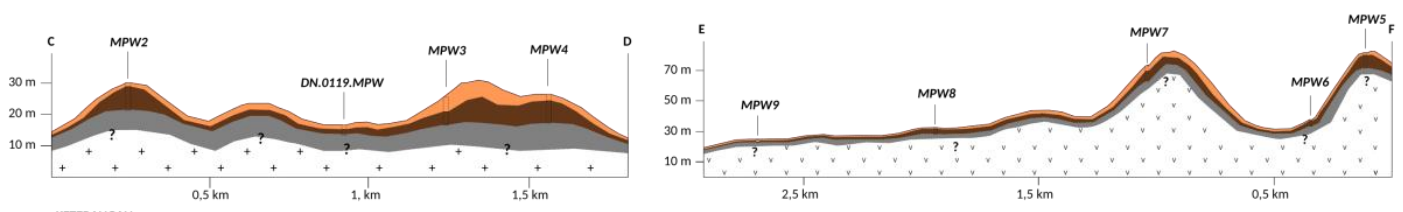

$\square$ Zona latosol
Zona bauksit
Zona alterit

Figure 2. Geological map, geological cross-section and bauxite profile of the study area.
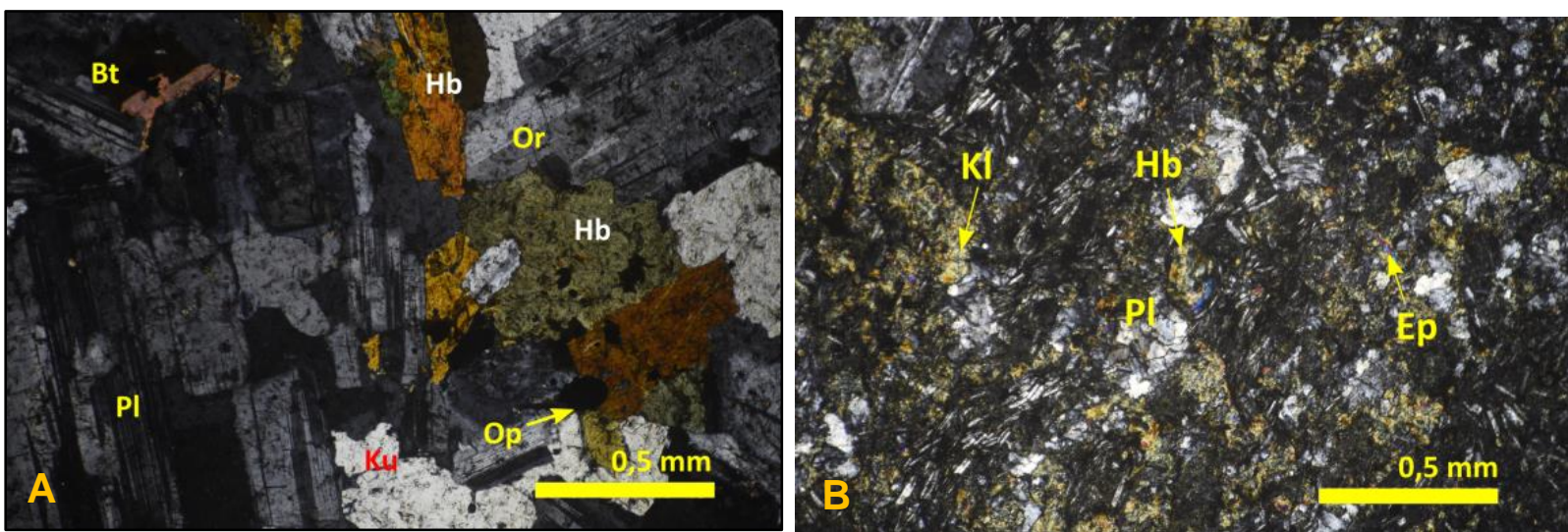

Figure3. Microscopic images of some bauxite parent rock: a) Microscopic image of granodiorite with ubiquitous plagioclase $(\mathrm{Pl})$, quartz $(\mathrm{Ku})$, hornblende $(\mathrm{Hb})$, biotite $(\mathrm{Bt})$ and opaque minerals $(\mathrm{Op})$; b) Epidote (Ep) and chlorite (K) replaced plagioclase and hornblende as the primary minerals of andesite. 
Texture and Mineralogy Characteristics of From this observation and laboratory analyses,

\section{Lateritic Bauxite}

The observation of vertical bauxite profile was carried toward outcrops and test pits. there is 3 main horizon of clay or pallid, bauxite and latosol horizon respectively from the bottom to top (Figure 4 and 5).

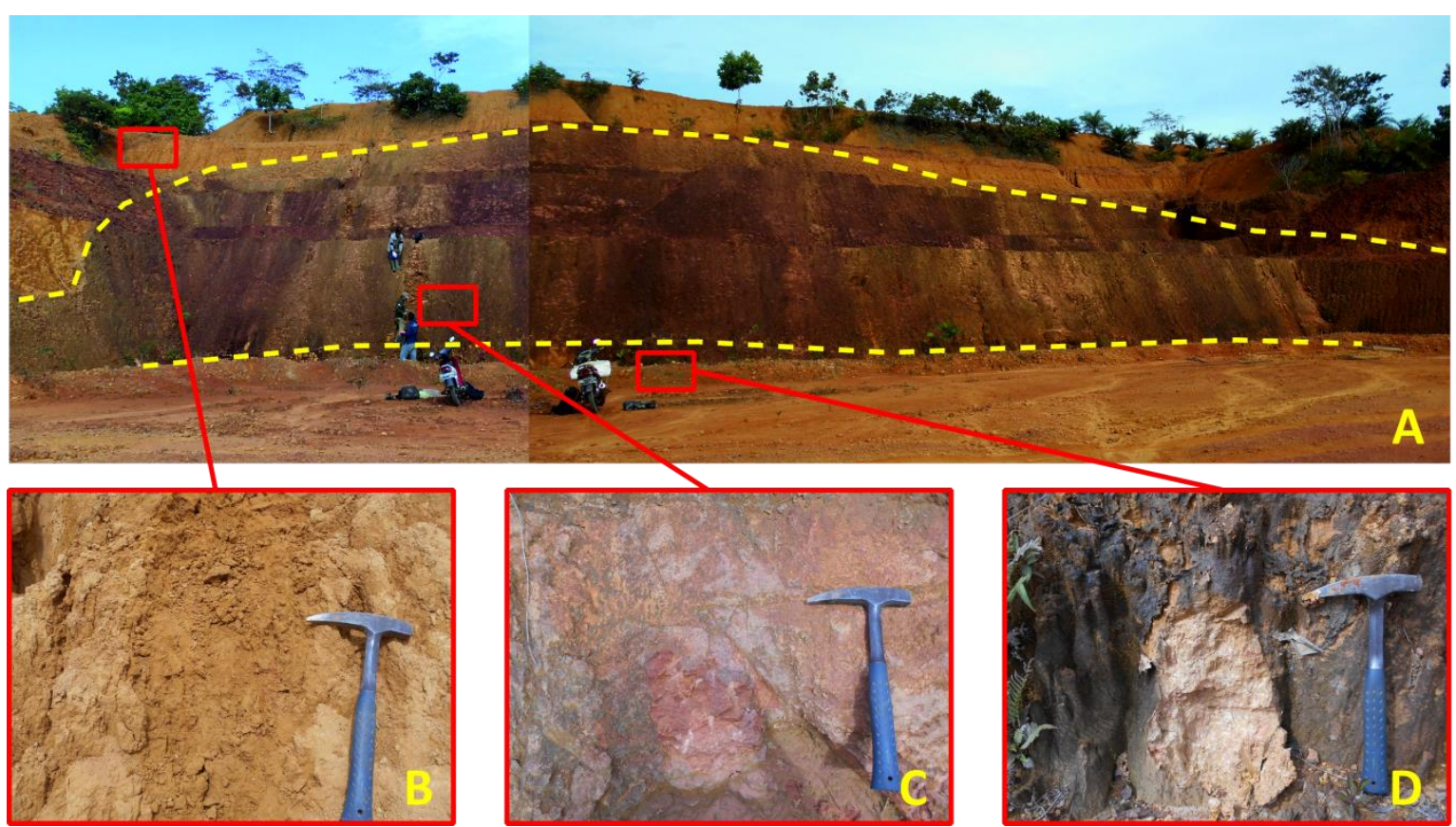

Figure 4: (a) The rock exposure depicts the vertical weathering profile of clay, bauxite and latosol horizon respectively from the bottom to top. The laterite derived from granodiorite parent rock; (b) Latosol exhibits brownish yellow; (c) Brownish red color of bauxite; and (d) relic texture of clay zone as indicated by white dots.

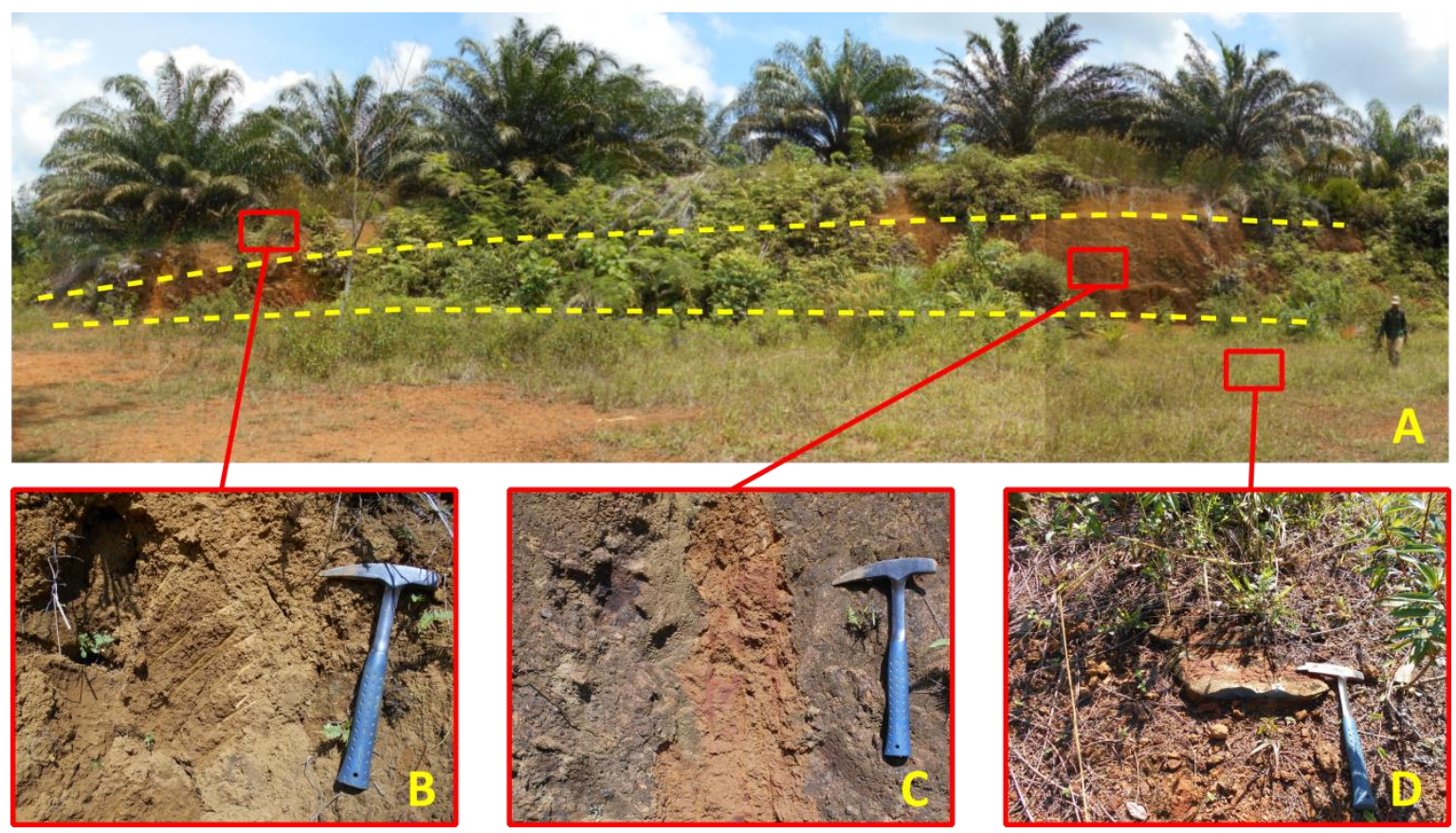

Figure 5: (a) Outcrop illustrates the vertical weathering profile of andesite parent rock consists of clay, bauxite and latosol horizon respectively from the bottom to top; (b) Latosol exhibits brown color; (c) Reddish-brown color of bauxite; (d) Boulder of andesite as the non-decomposed material within clay horizon. 


\section{IAGI Journal}

Megascopic identification of clay horizon derived from granodiorite exhibits brownish white color, with relic texture and friable. Most of the feldspar was replaced by kaolinite (Figure 6a). Hornblende has been altered to goethite during the leaching process, while biotite was altered to interstratified vermiculite and kaolinite with additional rimming of goethite (Figure 6b). Magnetite was replaced by goethite and hematite.

Clay horizon derived from andesite has different characteristics as evidenced by greenish-brown color with common relic texture. The horizon was composed of goethite and kaolinite, in which goethite replaced the primary minerals of olivine, hornblende and epidote; whereas kaolinite replaced plagioclase and chlorite minerals (Figure 7A).
Trace of hydrothermal minerals of pyrite and kaolinite were respectively replaced by goethite and covellite (Figure $7 b$ ).

Bauxite horizon exhibits brownish-red to reddish-brown, sandy to boulder-sized concretions embedded within clay matrix without any relict texture. In general, bauxite has massive concretion. The clay matrix is composed of kaolinite, goethite, gibbsite, quartz, magnetite and hematite. Some features also display the alteration of pseudomorph plagioclase into kaolinite and subsequently replaced by gibbsite, particularly observed within bauxite samples derived from granodiorite (Figure 6c and 6d). Ferricrete presents as sealing of the upper bauxite horizon.
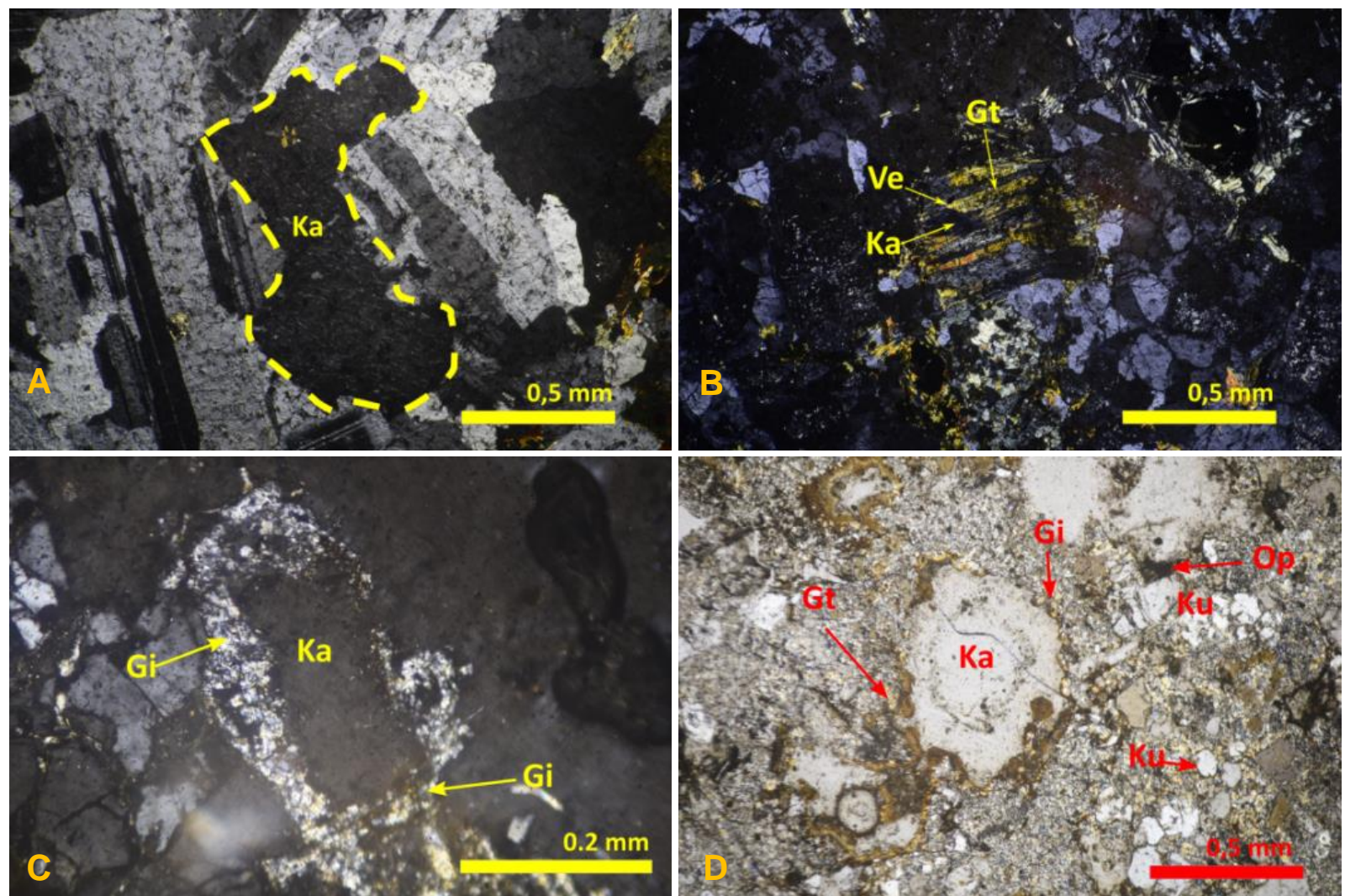

Figure 6. Microscopic image of clay and bauxite samples derived from the weathering of granodiorite. (a) Pseudomorph feldspar is replaced by kaolinite (Ka); (b) Biotite alters to interstratified vermiculite (Ve) and kaolinite with additional goethite (Gt); (c) Pseudomorf feldspar initially replaced by kaolinite but subsequently overprinted by gibbsite $(\mathrm{Gi})$; (d) Quartz $(\mathrm{Ku})$, opaque mineral $(\mathrm{Op})$, and kaolinite with the rim of goethite and gibbsite. 

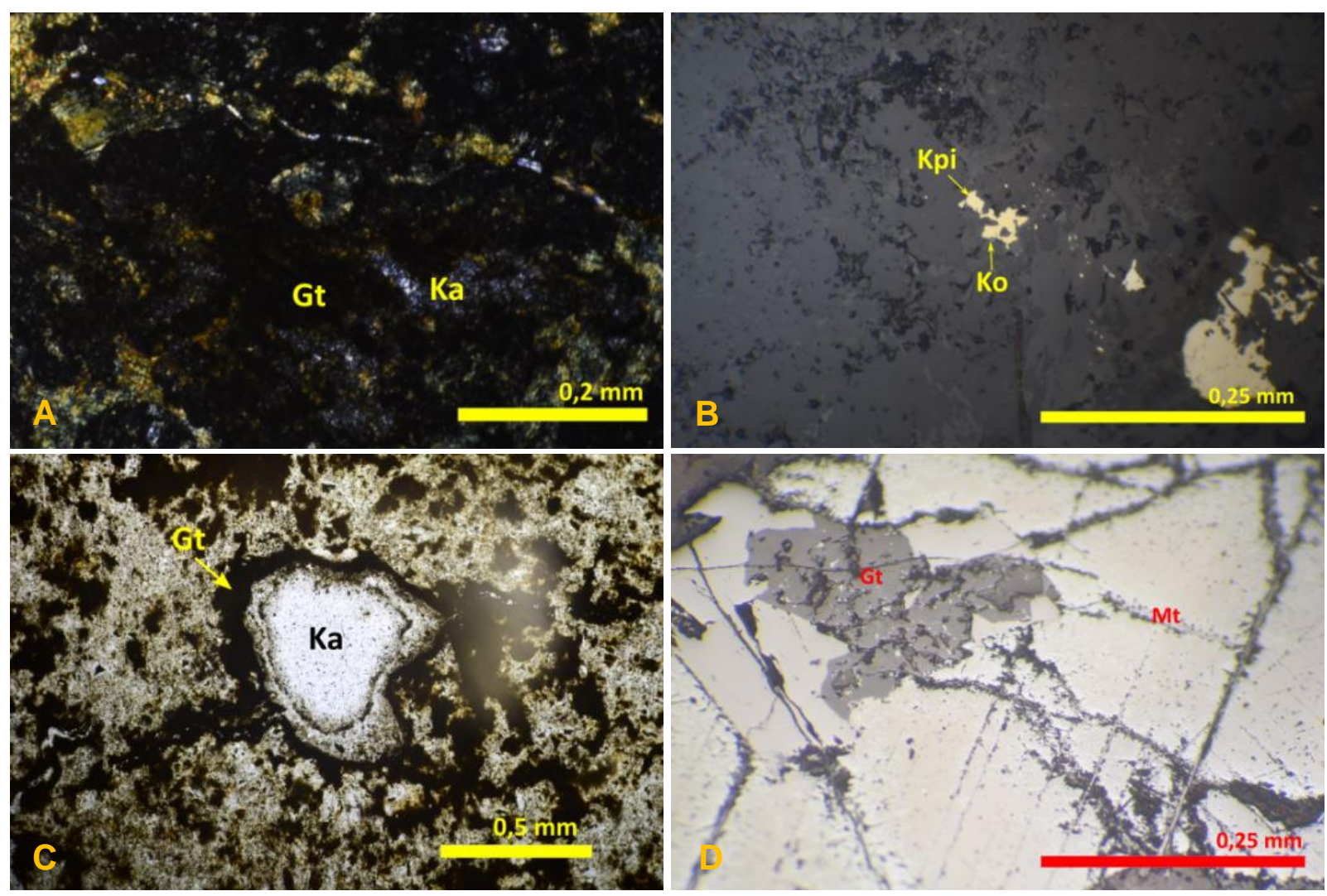

Figure 7. Photomicrograph depicts clay and bauxite composition under the polarized microscope. Sample derived from andesite parent rock; (a) Goethite (Gt) and kaolinite (Ka) as secondary minerals; (b) Covellite (Ko) replaced chalcopyrite (Kpi); (c) Cluster of kaolinite which is surrounded by goethite as replacement minerals; (D) Magnetite (Mt) is replaced by goethite.

Bauxite derived from andesite contains minor quartz with abundant goethite minerals (Figure 7c). This iron mineral was replaced the primary mineral of magnetite. The uppermost horizon of latosol (lateritic soil) exhibits brownish yellow to brown with common silty to clayey-size particles. No relic texture was observed on this horizon. In regards to the three horizons with distinct physical and mineralogical characteristics as described above, bauxite can be classified as the type of ortho-bauxite [7].

\section{Geochemical Data of Bauxite Profile}

Bauxite derived from granodiorite, contains $\mathrm{SiO}_{2}$ which ranges from 28,849$54,255 \%, \mathrm{Al}_{2} \mathrm{O}_{3} 38,974-58,090 \%$, and $\mathrm{Fe}_{2} \mathrm{O}_{3}$ $6,504-19,041 \%$, geochemical data reveals that bauxite samples underwent low to moderate lateritization. Bauxite from andesite contains $\mathrm{SiO}_{2}$ ranges from 2,518-31,237\%, $\mathrm{Al}_{2} \mathrm{O}_{3} 28,432-71,702 \%$, and total $\mathrm{Fe}_{2} \mathrm{O}_{3}$ $25,269-43,981 \%$, it suggests that the bauxite experienced moderate to strong lateritization.

The plotted geochemical data to Schellman diagram [8] shows the enrichment pattern of $\mathrm{Al}_{2} \mathrm{O}_{3}$ and $\mathrm{Fe}_{2} \mathrm{O}_{3}$ increased subsequently to the top horizon; while $\mathrm{SiO}_{2}$ decreased subsequently relative to parent rock. Bauxite derived from andesite has fair grade range from $28,432-71,702 \%$ for $\mathrm{Al}_{2} \mathrm{O}_{3}$ and 25,269-43,981\% for $\mathrm{Fe}_{2} \mathrm{O}_{3}$ total. The grade of $\mathrm{Fe}_{2} \mathrm{O}_{3}$ from sample MPW5-B jump significantly as compared to other samples of MPW5. The value for $\mathrm{SiO}_{2}$ from sample MPW7 has a lower grade than other test pit samples. 


\section{Genetic of Bauxite Laterite}

The genetic occurrence of bauxite in the study area is divided into 2 stages, 1) clay-zone formation, 2) bauxite formation. Both were distinguished based on the presence of secondary minerals during the leaching process, and their major elements of $\mathrm{SiO}_{2}$, $\mathrm{Al}_{2} \mathrm{O}_{3}$ and $\mathrm{Fe}_{2} \mathrm{O}_{3}$. The clay horizon is indicated by the existence of abundant secondary clay minerals as produced by the leaching process of host minerals. The surficial process has altered primary minerals to secondary minerals [9]; [10].

Secondary kaolinite mineral replaces plagioclase, orthoclase, sericite and chlorite. Goethite replaces hornblende, olivine, epidote and magnetite. Biotite is mainly replaced by interstratified vermiculite, kaolinite and goethite. Sulphide minerals have also experienced alteration during the formation of clay, as such pyrite has been replaced by goethite and chalcopyrite has been replaced by covellite as rim minerals.

Weathering and leaching processes due to perpetual groundwater circulation are possibly generating the bauxite laterite. In general, bauxite is composed of kaolinite, gibbsite, goethite, quartz, magnetite with lesser hematite. The weathering process has altered the primary texture, remained resistant and secondary minerals. Gibbsite is known as bauxite ore which presents as kaolinite replacement and fills the mineral cracks.

The subsequent alteration from the parent rocks to clay and bauxite zone indicates the characteristic of indirect bauxitization. The incomplete hydrolysis causes the dissolution of some mobile elements. Fe, $\mathrm{Al}$ and partial $\mathrm{Si}$ elements were accumulated locally as kaolinite and goethite. Kaolinite presents as a pseudomorph of the host mineral, while goethite presents as infilling minerals within cracks [11].

Sample MPW5-B shows an elevated grade of $\mathrm{Fe}_{2} \mathrm{O}_{3}$ significantly than that from test pit MPW5. $\mathrm{SiO}_{2}$ grade from test pit MPW7 has a low value. It is caused by the presence of hydrothermal alteration minerals and the changes of physio-chemical condition, including the groundwater $\mathrm{pH}$ and $\mathrm{Eh}$ as caused by the interaction of groundwater and sulphide minerals.

Hydrothermal alteration involves the circulation of hydrothermal fluid and leading to the physiochemical alteration of adjacent fractures. The interaction of hydrothermal fluid and rocks lead to the imbalance chemical condition during dissolution and precipitation of neomorphic minerals [12]. The transformation of texture, mineralogy and chemical composition of the host rock determines the weathering product.

Iron and aluminum elements have immobile characteristics during chemical weathering under tropical climate conditions. Both are easily dissolved under low $\mathrm{pH}$ condition $(\mathrm{pH}<4)$ and oxidized $(\mathrm{Eh}>0.4)$ [13]. Under this condition, dissolution of groundwater carries $\mathrm{Al}^{3+}$ and $\mathrm{Al}(\mathrm{OH})^{4-}$ ions that prevent the precipitation of gibbsite. Low $\mathrm{pH}$ condition is produced by the interaction of oxygen, meteoric water, sulphide mineral (i.e. pyrite, arsenopyrite and chalcopyrite [14].

\section{CONCLUSION}

Bauxite laterite in the Mempawah area is classified to orthobauxite type, with the vertical profile consists of clay, bauxite and latosol horizon, respectively from bottom to top. Bauxite occurs during indirect bauxitization of humid tropical climates. In general, bauxite exhibits massive texture, with concretion embedded within clay matrix and 
composed by assemblage minerals of kaolinite, goethite, gibbsite, quartz, magnetite and hematite. Bauxite derived from andesite exhibits reddish-brown, with predominant goethite and lesser quartz; meanwhile, bauxite derived from granodiorite exhibits brownishred contains greater quartz and lesser goethite. The bauxite characteristics are reliant on the textural and mineralogical characteristics of the parent rock. Geochemically, bauxite from andesite has a greater grade range than that of bauxite derived from granodiorite. It is suspected that local hydrothermal alteration contributes to the diverse characteristics of neomorphic minerals.

\section{ACKNOWLEDGEMENT}

Authors would like to express gratitude to PT ANTAM Tbk. for valuable support during field data collection and sample analyses.

\section{REFERENCES}

1. Evans, A. M.; Ore Geology and Industrial Minerals, An Introduction, 3rd Ed. UK: Blackwell Science, 1993.

2. USGS; Mineral commodity summaries 2020, no. 703. US Geological Survey, 2020.

3. Gu, J.; Huang Z.; Fan H.; Jin Z.; Yan Z.; and Zhang J.; "Mineralogy, geochemistry, and genesis of lateritic bauxite deposits in the WuchuanZheng'an-Daozhen area, Northern Guizhou Province, China," Journal of Geochemical Exploration, vol. 130, pp. 44-59, 2013, doi: 10.1016/j.gexplo.2013.03.003.

4. Rodenburg, J. K.; "Geology, Genesis and Bauxite Reserves of West Kalimantan, Indonesia," Society for Mining, Metallurgy \& Exploration, 1984, pp. $603-618$
5. Suwarna, N. and Trail, D . S.; "Peta Geologi Lembar Singkawang, Kalimantan Skala 1:250.000," Pusat Penelitian dan Pengembangan Geologi, Bandung, 1993.

6. Hartono, U.; "Magmatism in Kalimantan," Special Publication, Centre for Geological Survey, Geological Agency, Ministry of Energy and Mineral Resources, 2012.

7. Tardy, Y.; Boeglin, J. P.; Novikoff, A.; and Roquid C.; "Petrological and Geochemical Classification of Laterites," Proceedings of the 10th International Clay Conference, 1993.

8. Schellmann, W.; "Geochemical differentiation in laterite and bauxite formation," Catena, vol. 21, no. 2-3, pp. 131-143, 1994, doi: 10.1016/03418162(94)90007-8.

9. Stoops, G. and Delvigne, J.; "Morphology of Mineral Weathering and Neoformation. II Neoformations," Developments in Soil Science, vol. 19, no. C, pp. 483-492, 1990, doi: 10.1016/S0166-2481(08)70363-5.

10. Kingston, M.; "Important Hydrothermal Minerals and Their Significance," Kingston Morrison Ltd., 1997.

11. Tardy, Y. and Nahon, D.; "Geochemistry of Laterites, Stability of Al-goethite, Al-hematite, Fe3+-kaolinite in Bauxites and Ferricretes: An Approach to The Mechanism of Concretion Formation," 1985, American Journal of Science, pp. 865-903.

12. Pirajno, F.; "Hydrothermal Processes and Mineral Systems," 2009, pp. 1025-1096.

13. Lelong, F.; Tardy, Y.; Grandin, G.; Trescases, J. J.; and Boulange, B.; "Pedogenesis, Chemical Weathering and Processes of Formation of Some Supergene Ore Deposits," Supergene and Surficial Ore Deposits, no. 3, pp. 93-173, 1976, doi: 10.1016/b978-0-444-41403-8.50007-8.

14. Jacobs, J. A. and Testa, S. M.; "Acid Mine Drainage, Rock Drainage, and Acid Sulfate Soils," Acid Mine Drainage, Rock Drainage, and Acid Sulfate Soils, 2014, doi: 10.1002/9781118749197. 